\title{
Current concepts of maxillitis pathogenesis and morphogenesis (a literature review)
}

\author{
Yu. M. Andreichyn ${ }^{1}$, V. A. Mikhniov ${ }^{2}$ \\ ${ }^{1}$ I. Horbachevsky Ternopil State Medical University, Ukraine, ${ }^{2}$ Bogomolets National Medical University, Kyiv, Ukraine
}

The aetiology of prenatal sinusitis as well as maxillitis is caused by bacteria, micromyces and viruses, often in combination. Acute infection spreads predominantly from meatus to paranasal sinuses resulting in rhinosinusitis development. Natural sinus fistula obstruction due to mucous membrane oedema, endotoxicosis, disorders of tissue immunity and mucociliary clearance, leukocytic infiltration, stimulation of oxygen active forms formation in leukocytes etc. are significant for the disease pathogenesis. As a result, inflammatory and dystrophic changes develop in all layers of sinus walls. The pathological process is affected by a number of confounding factors.

The aim of the research is to study the recent research publications for better comprehension of the main factors of maxillitis aetiology and pathogenesis taking into account our research data.

Conclusions. Maxillitis is caused by pathogenic and potentially pathogenic bacteria, fungi and viruses, which are usually spread to sinuses from meatus. Endotoxicosis, the decrease in tissue immunity and mucociliary clearance, inflammatory and dystrophic changes in mucosae and bone layer of sinus walls are very important for the pathogenesis. The significance of neurotrophic disorders is proven. The confounding factors take account of immunodeficiency, cryoglobulinemia, sinus fistula obstruction, adenoidal vegetation, anatomical anomalies of nose, hepatic insufficiency.

Key words: maxillary sinusitis, pathology, confounding factors.

Zaporozhye medical journal 2018; 20 (2), 265-269 DOI: 10.14739/2310-1210 2018.2.125358

E-mail: yuraandr@gmail.com

\section{Сучасні уявлення про пато- і морфогенез верхньощелепних синуситів (огляд Аітератури)}

\section{Ю. М. Анарейчин, В. А. Міхньов}

Етіологія приносових синуситів, зокрема верхньощелепних, зумовлена бактеріями, мікроскопічними грибами та вірусами, часто в поєднанні. На приносові пазухи гостра інфекція поширюється переважно з носових ходів, призводячи до розвитку риносинуситу. У патогенезі важливу роль відіграє блокування природних співусть пазух унаслідок набряку слизової оболонки, ендотоксикозу, порушення місцевого імунітету та мукоциліарного кліренсу, лейкоцитарна інфрільтрація, стимуляція утворення активних форм кисню в лейкоцитах тощо. Внаслідок цього розвиваються запально-дистрофічні зміни в усіх шарах синусних стінок. На патологічний процес впливає низка обтяжливих фракторів.

Мета роботи - проаналізувати наукові публікації останніх років для кращого розуміння основних чинників етіології та ланок патогенезу верхньощелепних синуситів із врахуванням даних власних досліджень.

Висновки. Верхньощелепні синусити спричиняються патогенними та умовно-патогенними бактеріями, грибами та вірусами, котрі найчастіше поширюються на синуси з носових ходів. У патогенезі важливу роль відіграють ендотоксикоз, зниження місцевого імунітету та мукоциліарного кліренсу, запально-дистрофічні зміни слизових оболонок і кісткового шару синусних стінок. Доведене важливе значення нейротрофічних порушень. До обтяжливих факторів належать імунодефіцитні стани, кріоглобулінемія, порушення прохідності співусть, аденоїдні вегетації, анатомічні аномалії носа, печінкова недостатність.

\section{Современные представления о пато- и морфогенезе верхнечелюстных синуситов (обзор митературы)}

\section{Ю. М. Анарейчин, В. А. Михнев}

Этиология околоносовых синуситов, и в частности верхнечелюстных, обусловлена бактериями, микроскопическими грибами и вирусами, часто в сочетании. На околоносовые пазухи острая инфекция распространяется преимущественно из носовых ходов, приводя к развитию синусита. В патогенезе важную роль играет блокировка природных соустий пазух вследствие отека слизистой оболочки, эндотоксикоза, нарушения местного иммунитета и мукоцилиарного клиренса, лейкоцитарная инфильтрация, стимуляция образования активных форм кислорода в лейкоцитах и т. п. В результате развиваются воспалительно-дистрофические изменения во всех слоях синусных стенок. На патологический процесс влияет ряд отягощающих факторов.

Цель работы - проанализировать научные публикации последних лет для лучшего понимания основных факторов этиологии и звеньев патогенеза верхнечелюстных синуситов с учетом данных собственных исследований.

Выводы. Верхнечелюстные синуситы вызваны патогенными и условно-патогенными бактериями, грибами и вирусами, которые чаще всего распространяются на синусы из носовых ходов. В патогенезе важную роль играют эндотоксикоз, снижение местного иммунитета и мукоцилиарного клиренса, воспалительно-дистрофические изменения слизистых оболочек и костного слоя синусных стенок. Доказано важное значение нейротрофических нарушений. К утяжеляющим факторам принадлежат иммунодефицитные состояния, криоглобулинемия, нарушение проходимости соустий, аденоидные вегетации, анатомические аномалии носа, печеночная недостаточность.
Киючові слова: верхньощелепний синусит, патологія, обтяжливі чинники.

Запорізький медичний журнал. - 2018. T. 20, № 2(107). -

C. $265-269$
Ключевые слова: верхнечелюстной синусит, патология, утяжеляющие факторы.

Запорожский медицинский журнак. - 2018. T. 20, № 2(107). C. 265-269 
The infection of sinuses with a variety of microbial flora (bacteria, fungi, viruses), which are spread mainly from meatus, take the first place in the aetiology of sinusitis [1]. Staphylococci, streptococcus, pneumococcus and Pfeiffer's bacillus are the most frequent [2,3]; rarely Proteus, Pseudomonas aeruginosa, S. pneumonia, H. influenzae, M. catarrhalis.

The aim of the research is to study the recent research publications for better comprehension of the main factors of maxillitis aetiology and pathogenesis taking into account our research data.

The results of our research have proved that the spectrum of microorganisms, which can be etiological factors of acute sinusitis, includes both gram-positive and gram-negative aerobic and optionally anaerobic bacteria. From the studied material, mostly microbial associations are predominantly distinguished (in $60 \%$ of the examined). Most bacteria strains proved high-adhesion properties [4].

Fungal flora is significant for the aetiology of sinusitis [5], which primarily is not an etiological factor of sinusitis but develops as a result of dysbiosis and may subsequently be dominant. Fungal sinusitis differs from bacterial one by more severe progression with a higher frequency of exacerbations.

Acute sinusitis usually develops as a complication of influenza and other acute respiratory infections with underlying compromised tissue and general immunity. In addition to influenza viruses, rhino-, adeno-, reo-, parainfluenza viruses, respiratory syncytial, corona viruses, Coxacchi viruses and $\mathrm{ECHO}$ are identified [6].

Viral infection causes a significant structural failure of respiratory epithelium even its destruction. This promotes bacterial invasion into deep layers of mucous membrane and formation of bacterial foci [7]. In time, epithelium metaplasia occurs into the transient and multi-layered flat epithelium and thickening of basal membrane that makes excreta release from submucosal glands difficult and leads to their atrophy. As a result, the synthesis of this excreta decreases and mucoid-serous layer thinners that causes frequent inflammation exacerbations.

Acute sinusitis may happen in cases of acute rhinitis as a result of infection spread from nasal mucosa to sinuses and disorder of sinuses barofunction [8]. The changes in paranasal sinuses involve the same changes in nasal cavity, so these diseases are defined as rhinosinusitis.

The block of natural sinus fistula and virulence of microorganisms that cause inflammation are the most important for the pathogenesis of acute sinusitis. Nasal respiratory failure caused by deformation of nasal septum, chronic polyposis rhinosinusitis and hyperplastic processes of nasal cavity, which decrease the drainage function of sinuses, is a contributing factor [9]. The disease is associated with the decreased activity of mucociliary transport system of the affected mucous membrane that causes a decreased resistance to infection, mucus congestion and contributes to the pathology progression [10]. Disorders of mucociliary transport mechanisms are the change in frequency and amplitude of cilia beat, duration of effective beat, ratio of recovery period and period of effective beat, as well as in course of cilia movement. The violation of nose and sinuses mucosa epithelium ultrastructure is the most significant of these functional changes.
Side wall of a nose is principal in the inflammatory processes formation in paranasal sinuses. The pathology of osteomalal complex (zone of natural sinus fistula) causes obstruction of sinuses venting holes and their insufficient aeration and pathological contents evacuation [11]. The main factors are: violations of natural sinus fistulae associated with the swelling of nasal cavity mucosa [12], its hyperplasia and various anatomical anomalous features. Endoscopy of nose cavity and maxillary sinus revealed anatomical structural disorders of osteomalactic complex that leads to a block of natural sinus fistulae: enlarged ethmoidal bulla, hyperpneumatization of agger nasi cellule, enlarged ancyroid process of ethmoidal bone, changes in nasal valve, etc.

Adenoidal vegetation is essential in the aetiology and pathogenesis of sinusitis. Children with adenoids often are diagnosed with maxillitis, clinically of different degrees $[13,14]$. In case of adenoids, the nose and throat are separated and the secretions that are delayed in nasal cavity easily get into maxillary sinus, especially when wiping, because air pressure decreases in it. In addition, adenoids cause venous stasis in nasal cavity, swelling of nose and sinuses mucous membrane, narrowing of venting holes that violates the maxillary sinus airway, and infection development causes maxillitis.

Allergic factor is important for the pathogenesis of maxillitis [15,16], staphylococci, streptococcus, micromyces, and allergic to house dust mite protein above all.

Chronic maxillitis develops with underlying significant quantitative and functional disorders of all levels of immune response [17,18], decrease in the content of immunoglobulins A, E, G, M classes and interferon in blood, inhibition of phagocytic activity of neutrophil granulocytes and decrease in secretory $\lg A$ in punctates of sinuses and saliva.

It is established that in phagocytosis the macrophages use active forms of oxygen (AFO) to neutralize phagocytosed bacteria. Our study of the AFO in pathogenesis of maxillitis in the experiment on guinea pigs proved that on the $15^{\text {th }}$ day of experimental sinusitis, in neutrophils the AFO content was in 1.73 times higher than normal $(P<0.02)$, on the $90^{\text {th }}$ day - in 2.22 times $(P<0.01)$. In the group of animals with sinusitis and toxic hepatitis at the same days this value was significantly higher than in the pigs with sinusitis only $(P<0.05-0.001)[19]$.

It is established [20] that often recurrent maxillitis can be caused by secondary immunodeficiency. In cases of this pathology, individual variability in the content of proinflammatory cytokines is noted - the increase in IL-1 $\beta$ and IL-2 level with underlying decrease in $\gamma$-interferon concentration in serum. In cases of chronic maxillitis combined with nasal polyposis, up-regulation $\mathrm{TH}_{2}$ of IL-4 and IL-5 cytokines is identified, IL-4 is associated with nasal polyps, and IL-5 potentiates the immune response of fibroblasts; IL-8 is subjected to up-regulation by epidermal staphylococcus [21].

In cases of acute chronic maxillitis, lipid peroxidation increases while the activity of antioxidant defence enzymes decreases [22]. Such an imbalance of oxidants can cause the development of oxidative stress that is characterized by additional production of active forms of oxygen. Uncontrolled generation of these forms and their derivatives causes damage to nucleic acids, enzyme systems, biomembranes that intensifies the pathological process. Investigation of 


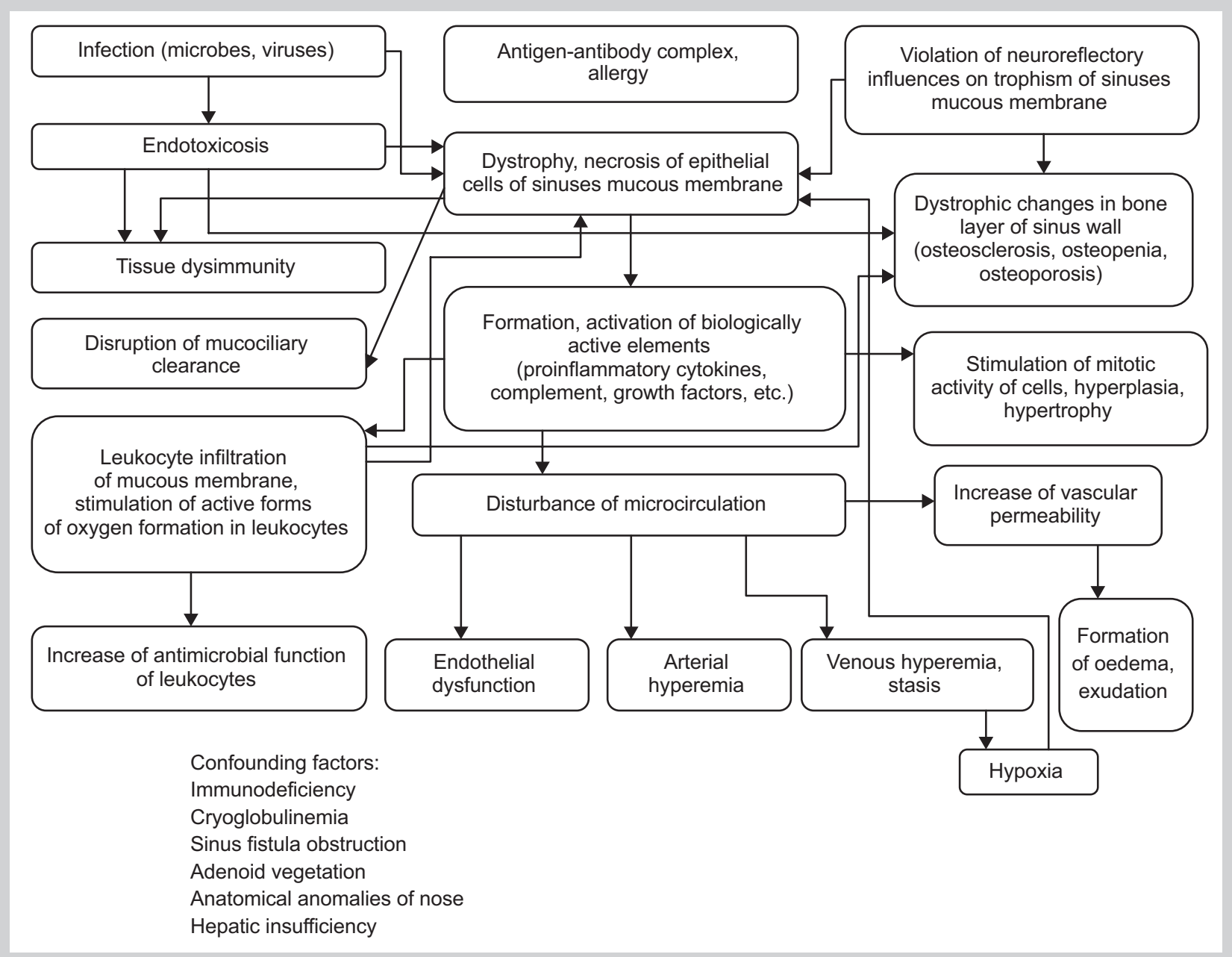

Fig. 1. The main factors of aetiology and pathogenesis of maxillitis.

rheological properties of peripheral blood in cases of purulent inflammation of sinuses [23] proved a disturbance in erythrocyte deformity, increase in their aggregation, as well as changes of their shape and volume. The importance of rheological disorders is directly related to intoxication degree and inflammatory process prevalence.

In cases of chronic polyposis maxillitis and ethmoiditis, hypoxia, endogenous intoxication and metabolic abnormalities are the most significant among various pathological changes [23]. Similar signs occur in many diseases, toxic and viral hepatitis in particular. However, in these processes in cases of sinusitis liver has not been studied, even though it is involved into all types of metabolism and is crucial for detoxification of the body.

Endothelial dysfunction is one of the characteristic components of many diseases development, both infectious and non-infectious. Its dysfunction is essential in inflammation and dystrophy of tissues development, because it causes changes in vascular wall permeability and rheological properties of blood, is involved into haemostasis, affects the activity of platelets and leukocytes. The Villebrand factor and thrombomodulin may be objective markers of endothelial dysfunction.

In patients with acute and chronic purulent maxillitis at the beginning of in-patient treatment, that is at the height of the disease [24], the concentration of the Villebrand factor was significantly higher than normal $(P<0.02-0.03)$. At the early stage of convalescence, when patients were dismissed from hospital, the Villebrand factor was significantly lower than at the beginning of the treatment.

In the height of the disease, the concentration of thrombomodulin in blood serum of the patients with both acute and chronic purulent maxillary sinusitis was significantly higher than normal $(P<0.02)[25]$.

Autonomic nervous system is very important for the development and pathogenesis of sinusitis, since it controls the secretion of mucosa glands and its vessels tone. Clinical and experimental studies [26] prove that in the chain of etiological and pathogenetic factors that predispose to the development of sinusitis; neurotrophic disorders are significant and often determining, because they provide a favourable conditions for further disease-causing involvement of bacterial flora. The trigeminal nerve transection in a rabbit allows obtaining a sinuses inflammation pattern, which can be used for studying the significance of nervous trophy disorder in pathogenesis of chronic maxillitis [27].

Experimental maxillitis, firstly simulated in guinea pigs by intersection of upper cervical sympathetic ganglion, caused structural changes in mucous and submucous 
tissue of denervated sinus. At the $15^{\text {th }}$ and $35^{\text {th }}$ days of the experiment, the increase of mucosa swelling (associated with accumulation of serous exudate and leukocyte infiltration), dystrophic and necrotic changes in epitheliocytes and a sharp decrease in their regenerative activity were evidenced. At $70^{\text {th }}$ day, the mucous membrane thickening was observed due to the expressed hyperplasia of epithelial cells, which was manifested by the extension of their cytoplasm and nucleus, that proves high mitotic activity. Subsequently ( $90^{\text {th }}$ day) there were some structural changes: hyperplasia and severe lymphocytic infiltration. Structural changes of the affected sinus bone plate were noticed: decreasing of its thickness $\left(15-90^{\text {th }}\right.$ day of the experiment), osteodystrophy development and osteopenia signs [28].

The course of experimental sinusitis caused by intersection of the upper cervical sympathetic ganglion in guinea pigs with underlying tetrachloromethane hepatitis was characterized by a more intensive structural reconstruction of all layers of denervated sinus wall and intensification of dystrophic and necrotic changes, oedema and proliferative processes. The tissue resorption of bone layer increased due to the reduction of intercellular matrix synthesis, decrease in the number of osteoblasts and increase in the number of osteoclasts. In this combined pathology the concentration of medium mass molecules (MMM) $\mathrm{MMM}_{254}, \mathrm{MMM}_{280}$ in serum and content of active forms of oxygen in neutrophilic leukocytes and lymphocytes were higher than in animals with sinusitis only [29].

The pathogenesis of maxillitis considering the results of the experimental studies is presented in the Fig. 1.

The study of pathogenetic influence of the disorders of sympathetic innervation, tissue immunity, microcirculation, endotoxicosis, content of free forms of oxygen and changes in hepatic functions on the development of inflammatory and dystrophic as well as sclerotic processes in mucous membrane and submucous tissue, as well as osteosclerosis and osteoporosis of maxillary sinus walls in cases of acute and chronic sinusitis in experiment and clinical setting is important for the development of new, high-efficient treatment.

\section{Conclusions}

1. Pathogenic and potentially pathogenic bacteria, fungi and viruses, which are usually spread to sinuses from meatus, are the main etiological factors of maxillitis.

2. Endotoxicosis, disorders of tissue immunity and mucociliary clearance, inflammatory and dystrophic changes in mucous membrane and bone layer of sinus walls and development of osteosclerosis, osteopenia and osteoporosis are crucial for the pathogenesis.

3. In the experiment on laboratory animals, significant influence of neurotrophic disorders on the development of acute and chronic maxillitis has been proved.

4. Immunodeficiency, cryoglobulinemia, adenoid vegetations, anatomical anomalies of nose, hepatic failure are the confounding factors.

\section{References}

[1] Byrjalsen, A., Ovesen, T., \& Kjaergaard, T. (2014). Staphylococcus aureus is a major pathogen in severe acute bacterial rhinosinusitis. Rhinology, 52(1), 48-52. doi: 10.4193/Rhin.
[2] Dong, D., Thomas, N., Thierry, B., Vreugde, S., Prestidge, C. A., \& Wormald, P. -J. (2015). Distribution and Inhibition of Liposomes on Staphylococcus aureus and Pseudomonas aeruginosa Biofilm. PLoS One., 10(6), e. 0131806. doi: 10.1371/journal.pone.0131806.

[3] Eviatar, E., Sandbank, J., Kleid, S., \& Gavriel, H. (2014). The role of osteitis of the lamina papyracea in the formation of subperiosteal orbital abscess in young children. International Journal of Pediatric Otorhinolaryngology, 78(12), 2267-2337. doi: 10.1016/j.ijporl.2014.10.031.

[4] Andreychyn, Yu. M., Klymnyuk, S. I., \& Pokryshko, O. V. (2014). Mikroflora verkhnoshchelepnykh pazukh i yii adhezyvna aktyvnist pry hostromu hniinomu synusyti [Microflora of the maxillary sinus and its adhesive activity in acute purulent sinusitis]. Infektsiini khvoroby, 3, 69-73. [in Ukrainian].

[5] Jain, R., Singhal, S. K., Singla, N., Punia, R. S., \& Chander, J. (2015) Mycological Profile and Antifungal Susceptibility of Fungal Isolates from Clinically Suspected Cases of Fungal Rhinosinusitis in a Tertiary Care Hospital in North India. Mycopathologia, 180(1-2), 51-60. doi: 10.1007/ s11046-015-9873-6.

[6] Popovich, V. I., \& Koshcel, I. V. (2013). Porivnialna efektyvnist roslynnoho fitonirynhovoho preparatu z kompleksnoiu diieiu ta syntetychnoho protyzapalnoho zasobu $v$ likuvanni ditei z nehniinymy formamy hostroho rynosynuitu [Comparative effectiveness of herbal phytoneering drug with a complex action and synthetic anti-inflammatory drugs in treating children with acute purulent rhinosinusitis]. Rynolohiia, 3 , 25-31. [in Ukrainian].

[7] Maliarenko, T. V. (2009). Dosvid zastosuvannia preparatu «Fromilid-uno» pry bakterialnykh rynosynuitakh [The experience of using the drug «Fromilid-Uno» duringbacterial rhino sinusitis]. Zhurnal vushnykh, nosovykh i horlovykh khvorob, 3, 74-77. [in Ukrainian].

[8] Podovzhnii, O. H., Sonnik, N. B., \& Loburets, A. V. (2013). Rynohenn ta odontohenni verkhnoshchelepni synusyty: osoblyvosti diahnostyky [Rhinogenic and odontogenic maxillary sinusitis: features ofdiagnosis]. Zhurnal vushnykh, nosovykh i horlovykh khvorob, 5, 177-178. [in Ukrainian].

[9] Talalaenko, I. A., \& Boenko, S. K. (2010). Izmeneniya ostiomeatal'nogo kompleksa u pacientov s khronicheskimi vospalitel'nymi zabolevaniyam perednej gruppy okolonosovykh pazukh [Alterations of osteometal complex in patients with chronic inflammatory disease of frontal paranasal sinuses]. Zhurnal vushnykh, nosovykh i horlovykh khvorob, 6, 30-35. [in Russian].

[10] Zavalii, M. A., \& Bezshapochny, S. B. (2010). Analiz klinicheskikh simptomov i fiziko-khimicheskikh pokazatelej funkcii mukocilyarnoj transportnoj sistemy u bol'nykh ostrym gnojnym sinusitom [Analysis of clinical symptoms and physicochemical parameters of mucociliary transport system function in patients with acute purulent sinusitis] Rynolohiia, 4, 3-14. [in Russian].

[11] Demenkov, V. R., Pristavko, T. M., \& Vatanskaya, I. Yu. (2012). Mestnoe i obshchee lechenie bol'nykh s ostrymi gnojnymi sinusitami [Local and general treatment of patients with acute purulentsinusitis]. Zhurnal vushnykh, nosovykh i horlovykh khvorob, 5, 48-49. [in Russian].

[12] Kosakovskij, A. L., \& Bezshapochnyj, S. B. (2010). Pro zastosuvannia preparativ «Umkalor» ta «Tsynabsyn» pry likuvanni khvorykh na hostryi rynosynusyt [About application of preparations «Umckalor» and "Cinnabsin» at the treatment of the patients with acute rhinosinusitis]. Zhurnal vushnykh, nosovykh i horlovykh khvorob, 6, 36-41. [in Ukrainian].

[13] Anfuso, A., Ramadan, H., Terrell, A., Demirdag, Y., Walton, C., Skoner, D. P., \& Piedimonte, G. (2015). Sinus and adenoid inflammation in children with chronic rhinosinusitis and asthma. Annals of Allergy, Asthma and Immunology, 114(2), 103-110. doi: 10.1016/i.anai.2014.10.024

[14] Evcimik, M. F., Dogru, M., Cirik, A. A., \& Nepesov, M. I. (2015). Adenoid hypertrophy in children with allergic disease and influential factors. International Journal of Pediatric Otorhinolaryngology, 79(5), 694-697. doi: 10.1016/j.ijporl.2015.02.017

[15] Dutta, R., Dubal, P. M., \& Eloy, J. A. (2015). The connection between seasonal allergies, food allergies, and rhinosinusitis: what is the evidence? Current Opinion in Otolaryngology \& Head and Neck Surgery, 23(1), 2-7. doi: 10.1097/MO0.0000000000000123.

[16] Doellman, M., Chen, P. G., McMains, K. C., Sarber, K. M., \& Weitzel, E. K. (2015). Sinus penetration of saline solution irrigation and atomizer in a cadaveric polyp and allergic fungal sinusitis model. Allergy Rhinology. (Providence), 6(1), 8-11. doi: 10.2500/ar.2015.6.0115.

[17] Madani, S. A., \& Hashemi, S. A. (2014). Characterisation of up-regulated immunoglobulins in patients with chronic rhinosinusitis. The Journal of the Pakistan Medical Association, 64(4), 382-387.

[18] Yoon, Y. H., Jin, K., Kwon, K. R., Kim, S. H., Rha, K. S., \& Kim, Y. M. (2014). The role of B cell Activating Factor (BAFF) expression on pathogenesis of nasal polyp in chronic rhinosinusitis with nasal polyposis Rhinology, 52(4), 390-396. doi: 10.4193/Rhin13.154.

[19] Andreichyn, Yu. M. (2014). Aktyvni formy kysniu pry poiednanni verkhnoshchelepnoho synusytu i toksychnoho hepatytu v eksperyment Oxygen active forms combined with maxillary sinusitis and toxic hepatitis in experiment]. Hepatolohiia, 1, 61-66. [in Ukrainian]. 
[20] Van Zele, T., Holtappels, G., Gevaert, P., \& Bachert, C. (2014). Differences in initial immunoprofiles between recurrent and nonrecurrent chronic rhinosinusitis with nasal polyps. The American Journal of Rhinology \& Allergy, 28(3), 192-200. doi: 10.2500/ajra.2014.28.4033.

[21] Otto, B. A., \& Wenzel, S. E. (2008). The role of cytokines in chronic rhinosinusitis with nasal polyps. Current Opinion in Otolaryngology \& Head and Neck Surgery, 16(3), 270-4. doi: 10.1097/MOO.0b013e$3282 \mathrm{fb} 2885$.

[22] Volkov, I. K. (2007). Antioksidantnaya terapiya pri khronicheskikh zabolevaniyakh legkikh u detej [Antioxidant therapy at chronic diseases of the lungs in children]. Pediatriya (prilozhenie k zhurnalu «Consilium Medicum»), 9(1), 43-44. [in Russian].

[23] Bezshapochnyi, S. B. Hasiuk, Yu. A. \& Balynskyi, V. O. (2013). Morfolohichni zminy u stromi nazalnykh polipiv [Morphological changes in the stroma of nasal polyps]. Zhurnal vushnykhykh, nosovykh i horlovykh khvorob, 3, 17-18. [in Ukrainian].

[24] Andreychyn, Yu. M. (2011). Klinichna otsinka hiperekspresii faktora Villebranda pry verkhnoshchelepnomu synusyti [Clinical evaluation of von willebrand factor at maxillary sinusitis]. Infektsiini khvoroby, 2, 54-56. [in Ukrainian]. doi: http://dx.doi.org/10.11603/1681-2727. 2011.2.578.

[25] Andreychyn, Yu. M. (2014). Trombomodulin yak marker endotelialnoi funktsii khvorykh na verkhnoshchelepnyi synusyt [Thrombomodulin as marker of endothelial function in patients whis maxillary sinusitis]. Zdobutky klinichnoi i eksperymentalnoi medytsyny, 2, 209-211. [in Ukrainian].

[26] Coffey, C. S., Mulligan, R. M., \& Schlosser, R. J. (2009). Mucosal expression of nerve growth factor and brain-derived neurotrophic factor in chronic rhinosinusitis. The American Journal of Rhinology \& Allergy, 23(6), 571-575. doi: 10.2500/ajra.2009.23.3412.

[27] Mikhnev, V. A., Kolomijceva, V. P., \& Fedotov, A. F. (1972). Nejrotroficheskie izmeneniya slizistoj obolochki pridatochnykh pazukh nosa krolikov pri e'ksperimental'nom narushenii simpaticheskoj innervacii [Neurotrophic changes in the mucous membrane of the rabbits' nose paranasalsinuses with experimental disturbances of sympathetic innervation]. Zhurnal vushnykhykh, nosovykh i horlovykh khvorob, 2, 76-80. [in Russian].

[28] Mikhnev, V. A., Andreichyn, Yu. M., \& Datsko, T. V. (2014). Morfolohichni zminy slyzovoi obolonky verkhnoshchelepnykh synusiv morskykh svynok pry eksperymentalnomu porushenni yii sympatychnoi innervatsii [Morphological changes in the mucous membrane of the maxillary sinuses of guinean pigs in experimental disruption of sympathetic innervation]. Zhurnal Natsionalnoi akademii medychnykh nauk Ukrainy, 1, 109-114. [in Ukrainian].

[29] Andreychyn, Yu. M. (2014). Modeliuvannia slyzovoi obolonky verkhnoshchelepnykh synusiv na tli toksychnoho hepatytu v eksperymenti [Experimental modeling of the mucosa maxillary sinusitis against on toxic hepatitis b]. Infektsiini khvoroby, 4, 61-63. [in Ukrainian].

\section{Information about authors:}

Andreichyn Yu. M., MD, PhD, DSc, Associate Professor,

Department of Otorhinolaryngology, Ophthalmology

and Neurosurgery, State Institution of Higher Education

"I. Horbachevsky Ternopil State Medical University of the Ministry

of Health of Ukraine".

Mikhniov V. A., MD, PhD, DSc, Corresponding Member of NAMS

of Ukraine, Professor, Department of Pathophysiology,

0 . O. Bogomolets National Medical University of the Ministry

of Health of Ukraine, Kyiv.

\section{Відомості про авторів:}

Андрейчин Ю. М., А-р меА. наук, Аоцент

каф. оториноларингології, офтальмології та нейрохірургії, АВНЗ «Тернопільський державний меАичний університет імені І. Я. Горбачевського МОЗ України".

Міхньов В. А., член-кор. НАМН України, А-р меА. наук, професор каф. патологічної фізіології, Національний меАичний університет імені О. О. Богомольця М0З України, м. Київ.

\section{Сведения об авторах:}

Андрейчин Ю. М., А-р меА. наук, Аоцент

каф. оториноларингологии, офтальмологии и нейрохирургии,

ГВУЗ «Тернопольский государственный меАицинский университет имени И. Я. Горбачевского МЗ Украины". Михнев В. А., член-кор. НАМН Украины, А-р меА. наук, профессор каф. патологической физиологии, Национальный медицинский университет имени А. А. Богомольца МЗ Украины, г. Киев.
Conflicts of Interest: authors have no conflict of interest to declare. Конфлікт інтересів: віАсутній.

Надійшла Ао редакції / Received: 27.09.2017

Після Аоопрацювання / Revised: 02.10.2017

Прийнято Ао Аруку / Accepted: 20.10.2017 